H. Hof, A. Christen, J. Hacker

\title{
Comparative Therapeutic Activities of Ciprofloxacin, Amoxicillin, Ceftriaxone and Co-trimoxazole in a New Model of Experimental Infection With Escherichia coli
}

Summary: A new mouse model for systemic infection with Escherichia coli is presented. Whereas in other models $10^{7}-10^{8}$ bacteria have to be injected into an animal to induce toxic effects resulting in death within 24 hours, now, only $10^{3}-10^{4}$ bacteria of an appropriate strain are required to produce a genuine infection characterized by an increase in the bacterial load over several days. The quantitative determination of bacterial counts per liver allows a more sensitive measurement than recording death rates. Furthermore, few animals are required for a definite result in contrast to the $\mathrm{LD}_{50}$ determination of other models. The salient point regarding this new model is that conditioning of animals has to be achieved by incorporating the inoculum into agar which is injected subcutaneously. The resulting infection is completely dependent on the $E$. coli

Zusammenfassung: Vergleichende therapeutische Aktivitäten von Ciprofloxacin, Amoxicillin, Ceftriaxon und Co-trimoxazol in einem neuen Versuchsmodell für die experimentelle Infektion mit Escherichia coli. Ein neues Mausmodell für eine systemische Infektion mit Escherichia coli wird vorgestellt. In anderen Infektionsmodellen müssen $10^{7}-10^{8} \mathrm{E}$. coli pro Maus injiziert werden, was zu einer Intoxikation führt, so daß die Tiere innerhalb von 24 Stunden sterben. In diesem neuen Modell wird eine echte Infektion mit nur $10^{3}-10^{4}$ Bakterien gesetzt, und es folgt dann über mehrere Tage hinweg eine deutliche Vermehrung der Erreger. Diese kann exakt quantitativ durch die Bestimmung der Keimzahlen in der Leber kontrolliert werden, was eine viel empfindlichere Methode darstellt als die Feststellung von Mortalitätsraten. Weiterhin werden dabei weitaus weniger Mäuse benötigt, um eine stichhaltige Aussage zu machen, als für eine Bestimmung der $\mathrm{LD}_{50}$ erforderlich sind. Der entscheidende Punkt dieses neuen Modells ist, daß die Infektion mit den niedrigen Keimzahlen gebahnt werden muß. Dies strain used. Whereas a hemolytic, uropathogenic strain is so virulent that an overwhelming infection develops within 48 hours after the injection of $10^{3}$ bacterial cells, a non-hemolytic variant of this strain is completely avirulent, being unable to multiply in spite of the potentiating agar. The hemolytic $E$. coli strain ATCC 25922 is intermediate in virulence. The bacterial counts per liver increase steadily until death occurs five to seven days after the injection of $10^{4}$ bacteria. This bacterial infection can be therapeutically influenced by daily treatment with various drugs. Ciprofloxacin, ceftriaxone and co-trimoxazole are able to cure the infection, whereas amoxicillin given orally is only moderately active against this ATCC strain, which is relatively resistant to amoxicillin.

geschieht dadurch, daß das Inokulum in verflüssigtem Agar suspendiert wird, bevor es subkutan injiziert wird. Der Infektionsverlauf ist wesentlich abhängig von der Natur des verwendeten E. coli-Stammes. Während z. B. ein hämolytischer, uropathogener Stamm so virulent ist, da $B$ die Tiere einer fulminanten Infektion nach Injektion von nur $10^{3}$ Keimen erliegen, ist eine nicht-hämolytische Mutante dieses Stammes völlig avirulent und kann sich selbst trotz der Beigabe von Agar nicht vermehren. Der hämolytische Stamm E. coli ATCC 25922 ist bezüglich seiner Virulenz intermediär, d. h. nach Injektion von $10^{4}$ Bakterien nimmt die Keimzahl pro Leber ständig zu und die Tiere sterben nach fünf bis sieben Tagen an dieser Infektion. Gerade dieser Infektionsverlauf kann durch tägliche Verabreichung von Chemotherapeutika beeinflußt werden. Ciprofloxacin, Ceftriaxon und Co-trimoxazol sind in der Lage, eine Ausheilung zu erzielen. Amoxicillin hat nach oraler Gabe nur eine mäßige Wirkung auf die Infektion mit diesem ATCC-Stamm, der auch gegen Amoxicillin relativ resistent ist.

\section{Introduction}

It is hard to define the therapeutic potential of a chemotherapeutic agent only by determining its in vitro activity, since many pharmacological and infectiological aspects cannot be simulated under these relatively simple condi-
Received: 19 December 1985/Accepted: 24 March 1986

Prof. Dr. med. Dr. med. habil. H. Hof, Dr. med. A. Christen, Institute of Hygiene and Microbiology, University of Würzburg, Josef-SchneiderStr. 2, D-8700 Würzburg;

Dr. rer. nat. J. Hacker, Institute of Genetics and Microbiology, University of Würzburg, Röntgenring 11, D-8700 Würzburg. 
tions. Thus, it is of special interest to test the efficacy of an antimicrobial substance in an in vivo model.

In this paper a new model of systemic infection in mice with Escherichia coli is described which seems to be suitable for therapeutic studies.

This new model is derived from the experimental design of Joiner et al. (1) and Reznikov, Hackendorf and Matthews (2). They infected animals subcutaneously with a combination of $E$. coli and Bacteroides fragilis suspended in a potentiating material. Whereas $E$. coli produces a systemic infection, $B$. fragilis is only found in a local abscess at the site of injection. We have found that a synergistic action of $B$. fragilis is obviously not necessary. Certain strains of $E$. coli alone, suspended in semi-solid agar as the potentiating material (3), are also able to produce a systemic infection which can be monitored quantitatively for several days by determining bacterial counts in the liver.

Using this new model, the therapeutic activity of ciprofloxacin, a new quinolone with high antibacterial (4) and therapeutic (5) activity, was examined and compared with that of well known antibacterial agents, such as amoxicillin, co-trimoxazole and ceftriaxone.

\section{Materials and Methods}

Bacteria: Bacteria were grown in tryptose phosphate broth (Difco, Detroit, U.S.A.) for $18 \mathrm{~h}$ at $37^{\circ} \mathrm{C}$. Appropriate dilutions were prepared in phosphate-buffered saline (PBS), pH 7.2. The E. coli strains used were strain $536(\mathrm{O} 6: \mathrm{K} 15: \mathrm{H} 31)$, its non-hemolytic mutant 536/21 (5) and strain ATCC 25922. The nalidixic acid-resistant mutants II, III and IV of E. coli ATCC 25922 were obtained by MNNG mutagenesis (6).

Antibacterial agents: Quinolones: nalidixic acid was bought from Sigma (Munich, F.R.G.). Ciprofloxacin (Pt.No. 958 508; 84.8\% activity) was a gift from Bayer AG (Leverkusen, F.R.G.).

Trimethoprim and sulfamethoxazole were obtained from Hoffmann-La Roche (Grenzach, F.R.G.) and were used in a ratio of $1: 20$ for in vitro tests. For the treatment of animals, the combination co-trimoxazole $\left(\right.$ Bactrim $\left.^{\circledR}\right)$ was used containing both substances in a ratio of $1: 5$. Ceftriaxone (Op. No. PT 3455; 81 . 5\% activity) was a gift of Hoffmann-La Roche, Basel, Switzerland. Amoxicillin (amoxicillin trihydrate BRL 2333; 86\% activity) was kindly supplied by Beecham, Neuss, F.R.G.

Determination of minimum inhibitory concentration (MIC): An agar dilution method was employed using Mueller-Hinton agar as nutrient. $0.6 \mu \mathrm{l}$ of a bacterial suspension adjusted to one half of a McFarland's No. 1 standard was transferred by means of a multipoint inoculator (Greiner, Nürtingen, F.R.G.) to the agar plates containing the different concentrations of the antimicrobial agents. The inoculated plates were incubated for $24 \mathrm{~h}$ at $37^{\circ} \mathrm{C}$. The MIC was taken as the lowest concentration of the antibacterial agents which did not allow visible growth.

Determination of in vivo activities: Female NMRI mice weighing about $25 \mathrm{~g}$ were obtained in SPF-state from the Central Institute for Laboratory Animals (Hannover, F.R.G.). They were held under conventional conditions and fed water and pellets ad libidum. $0.3 \mathrm{ml}$ of a bacterial suspension was mixed in the syringe with $0.5 \mathrm{ml}$ of $1.5 \%$ liquified tryptose phosphate agar $\left(48^{\circ} \mathrm{C}\right)$ and immediately injected subcutaneously into the back of a mouse. The bacterial counts in the suspension were determined by plating. Their numbers ranged from $10^{3}$ to $10^{6}$ in the various experiments.

Treatment with ciprofloxacin was initiated $6 \mathrm{~h}$ after infection. $2 \mathrm{mg}$, i.e. $80 \mathrm{mg} / \mathrm{kg}$, of this drug dissolved in $0.5 \mathrm{ml}$ water were given orally by means of a stomach tube twice a day. Similar doses of amoxicillin were also given orally, whereas co-trimoxazole as well as ceftriaxone were injected subcutaneously. $0.2 \mathrm{ml}$ of a preparation were injected at alternate sites into the back of an animal.

At different intervals after infection, five mice from each group were killed and the liver, as well as the spleen and kidneys, in some experiments were removed aseptically. The organs were homogenized in a Tenbroek tissue grinder (Bellco, Vineland, N.J., U.S.A.). Serial dilutions in PBS were transferred into Petri dishes and mixed with $20 \mathrm{ml}$ of liquified tryptose phosphate agar. After incubation at $37^{\circ} \mathrm{C}$ for $24 \mathrm{~h}$ the bacterial colonies were counted and the bacterial counts per organ were calculated.

\section{Results}

\section{Determination of the Minimum Inhibitory Concentration}

The parent strain ATCC 25922 was susceptible to amoxicillin, ceftriaxone, co-trimoxazole, nalidixic acid and ciprofloxacin, the latter substance being the most active compound. The three nalidixic acid-resistant mutants were also relatively resistant to ciprofloxacin (Table 1).

\section{Conditioning of Escherichia coli Infection in Mice}

The subcutaneous injection of $10^{8}$ cells of $E$. coli was lethal for mice, whereas $10^{6}$ cells were well tolerated (Table 2 ). One day after infection, virtually no bacteria could be isolated from the spleen or liver (data not shown). However, when $10^{6}$ cells mixed with agar were injected, the animals appeared ill and died within a few days (Table 2 ).

Table 1: In vitro susceptibilities of Escherichia coli to different antibiotics.

\begin{tabular}{|c|c|c|c|c|c|}
\hline \multirow[b]{2}{*}{ Bacterial strain } & \multicolumn{5}{|c|}{ Minimum inhibitory concentration (mel) } \\
\hline & Natidixic acid & Ciprofloxacin & Co-trimoxazole & Amoxicilin & Ceftriaxone \\
\hline Escherichia coli & & 0015 & 1 & 4 & \\
\hline $\begin{array}{l}\text { ATCC } 25922 \\
\text { Mutant II }\end{array}$ & 128 & 0.5 & 8 & 4 & $\begin{array}{l}0.06 \\
0.06\end{array}$ \\
\hline Mutant III & 128 & 0.5 & 8 & 4 & 0.125 \\
\hline Mutant IV & 128 & 0.5 & 8 & 4 & 0.125 \\
\hline
\end{tabular}


H. Hof et al.: Chemotherapy of E. coli Infection

Table 2: Conditioning of infections of NMRI mice by mixing the bacterial suspension with agar.

\begin{tabular}{|lc|}
\hline Animal group & Survival rate \\
\hline $\begin{array}{l}\text { Subcutaneous injection of } \\
10^{8} \text { Escherichia coli ATCC } 25922\end{array}$ & $0 / 10^{*}$ \\
\hline $\begin{array}{l}\text { Subcutaneous injection of } \\
10^{6} \text { Escherichia coli ATCC } 25922\end{array}$ & $10 / 10$ \\
\hline $\begin{array}{l}\text { Subcutaneous injection of } \\
10^{6} \text { Escherichia coli ATCC } 25922 \\
\text { suspended in agar }\end{array}$ & $0 / 10^{* *}$ \\
\hline
\end{tabular}

* Mice died within $24 \mathrm{~h}$;

** Mice died within 3-5 days.

A multiplication of bacteria apparently took place under these conditions, since the bacterial numbers in the liver determined on the days following infection definitely exceeded the inoculum dose. Different strains of $E$. coli varied in their ability to multiply within the host (Figure 1).

\section{Therapeutic Studies}

In untreated control mice infected with $E$. coli ATCC 25922, high bacterial counts were found in the liver and the animals died five days after infection. Oral treatment with $2 \times 2 \mathrm{mg}$ ciprofloxacin prevented death and resulted in a marked reduction of the bacterial counts. Even the moderately resistant mutant strain was eliminated, though somewhat less rapidly (Figure 2 ).

Treatment with $2 \times 2 \mathrm{mg}$ co-trimoxazole or with $2 \times 2 \mathrm{mg}$ ceftriaxone/day was also very efficient (Figure 3 ), whereas oral treatment with $2 \times 2 \mathrm{mg}$ amoxicillin/day was rather ineffective (Figure 3 ).

\section{Discussion}

The addition of a potentiating agent, for example agar, to the inoculum is a prerequisite for the establishment of true infection of mice with $E$. coli (Table 2). It is possible that the subcutaneous agar depot inaccessible to the defense mechanisms of the host inhibits rapid clearing of the infection. Local multiplication of bacteria may provide a focus from which spreading to distant organs may occur. On the other hand, invasion of the internal organs may be promoted by agar, which damages certain systemic defense systems (7).

Not every strain of $E$. coli, however, is able to multiply under such conditions (8). Injection of virulent strains results in the death of the animals within one or two days, whereas subcutaneous injection of avirulent strains has no effect in this model. The strain E. coli ATCC 25922 is of intermediate virulence, meaning that the development of a persistent infection is dependent on the infective dose (Figure 1). Various virulence factors, including hemolysin and fimbriae, contribute to the pathogenic potential of a strain (9).

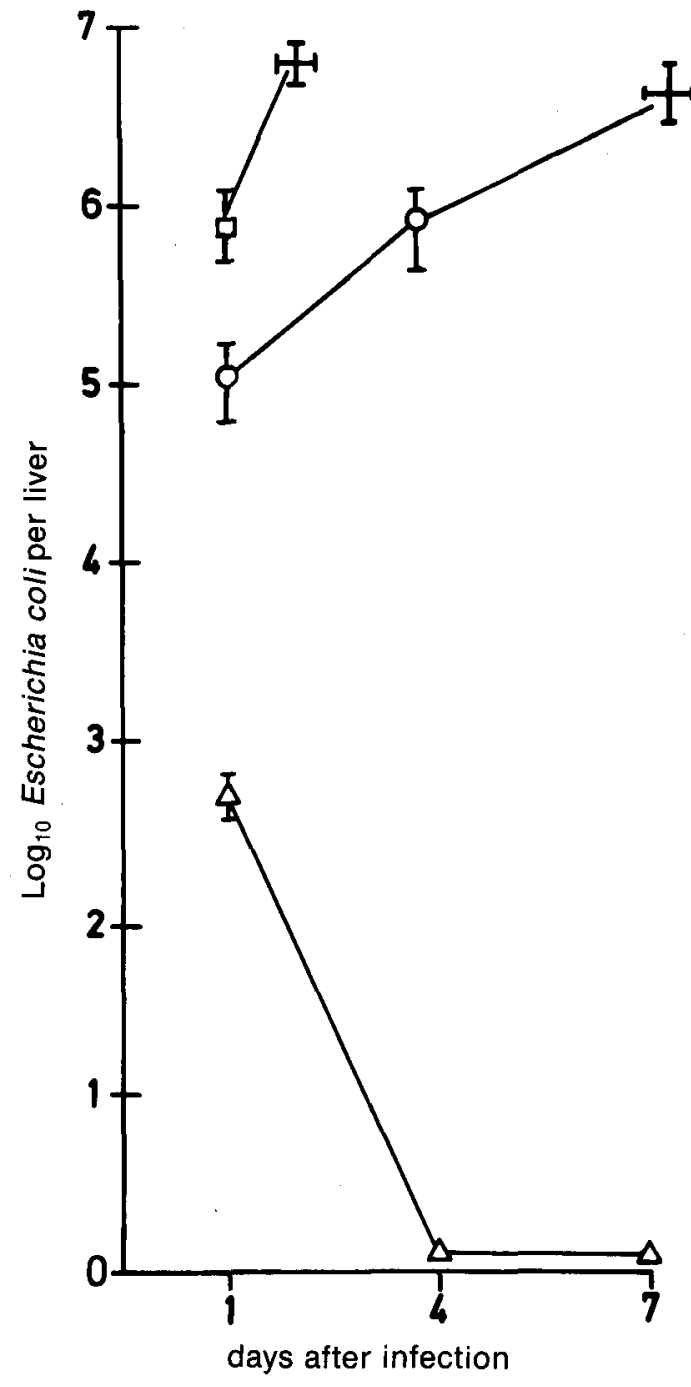

Figure 1: NMRI mice were infected subcutaneously with $5 \times 10^{3}$ cells of Escherichia coli $536(\square)$, ATCC $25922(0)$ or $536 / 21(\triangle)$ incorporated in agar. The mean \pm SE of bacterial counts per liver of five animals per group and day was determined.

The advantage of the experimental model of systemic infection of mice with $E$. coli ATCC 25922 that is presented here is that low infective doses (about $10^{3}$ bacteria) can be used for infection. Rapid multiplication clearly takes place in the animal, since 24 hours after subcutaneous injection, many more bacteria can already be isolated from the spleen, and especially from the liver, than were present in the inoculum. This infectious process continues for several days, depending on the infective dose. Consequently, the therapeutic efficacy of a drug can be monitored continuously. This model therefore differs fundamentally from other animal models where high, i.e. lethal doses of $E$. coli have to be injected (9). The premature death of animals injected with $10^{7}$ bacteria or more is due to toxic effects rather than to infection (Table 2). Furthermore, only small numbers of animals are required in this new model to achieve a definitive characterization of the 


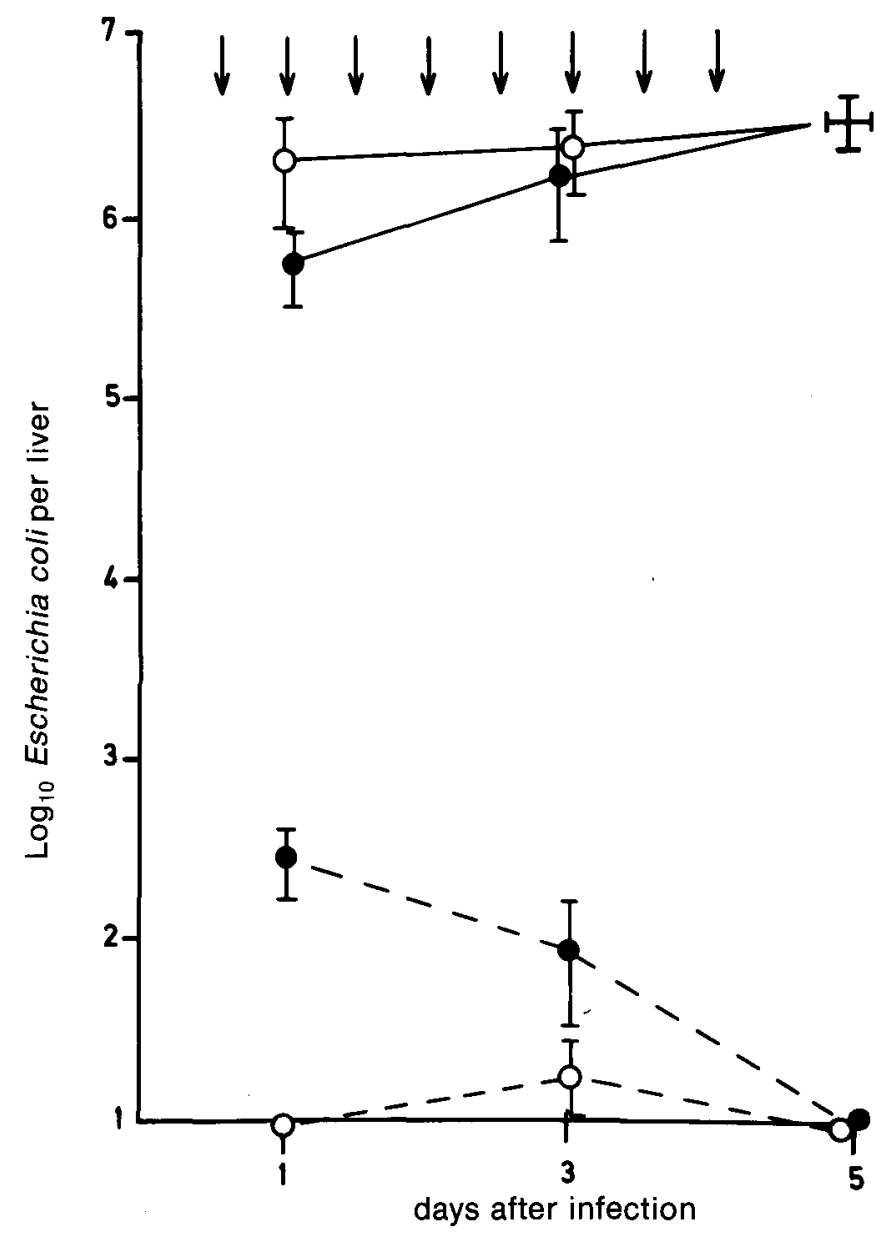

Figure 2: NMRI mice were infected subcutaneously with $10^{4}$ cells of Escherichia coli ATCC $25922(O)$ or its nalidixic acid-resistant mutant IV (๑) incorporated in agar. Mice from both groups were treated orally with $2 \times 2 \mathrm{mg}$ ciprofloxacin/day beginning $6 \mathrm{~h}$ after infection $(---O--1--0--)$. The mean \pm SE of bacterial counts per liver of five animals per group and day were determined.

therapeutic activity of a certain drug, whereas large numbers of mice are required for the determination of an $\mathrm{ED}_{50}$, which is a rather insensitive parameter.

Ciprofloxacin, an inhibitor of the subunit $\mathrm{A}$ of bacterial gyrase $(10)$, proved to be a very potent drug in this model since susceptible bacteria (Table 1 ) were eliminated very rapidly by oral treatment with $80 \mathrm{mg} / \mathrm{kg}$ twice daily. Even infection with the relatively resistant strain (Table 1 ) obtained by mutagenesis can be cured, although these bacteria disappear less rapidly (Figure 2). As reported by Smith (11), a high degree of resistance to ciprofloxacin could not be achieved by mutagenesis with MMNG, although these mutants were completely resistant to nalidixic acid (Table 1).

The therapeutic efficacy of $2 \times 80 \mathrm{mg} / \mathrm{kg} /$ day of amoxicillin given orally was rather low (Figure 3 ). This could be due either to a partial absorption of the drug or to the relatively low in vitro susceptibility of the E. coli ATCC 25922 strain, showing an MIC of $4 \mathrm{mg} / \mathrm{l}$ (Table 1). In contrast, a similar dose of ceftriaxone, given parenterally, was curative. Co-trimoxazole was also able to eliminate the bacteria.

In conclusion, it appears that this model of systemic infection with $E$. coli following local injection of low doses is suitable for the therapeutic evaluation of antibacterial agents.

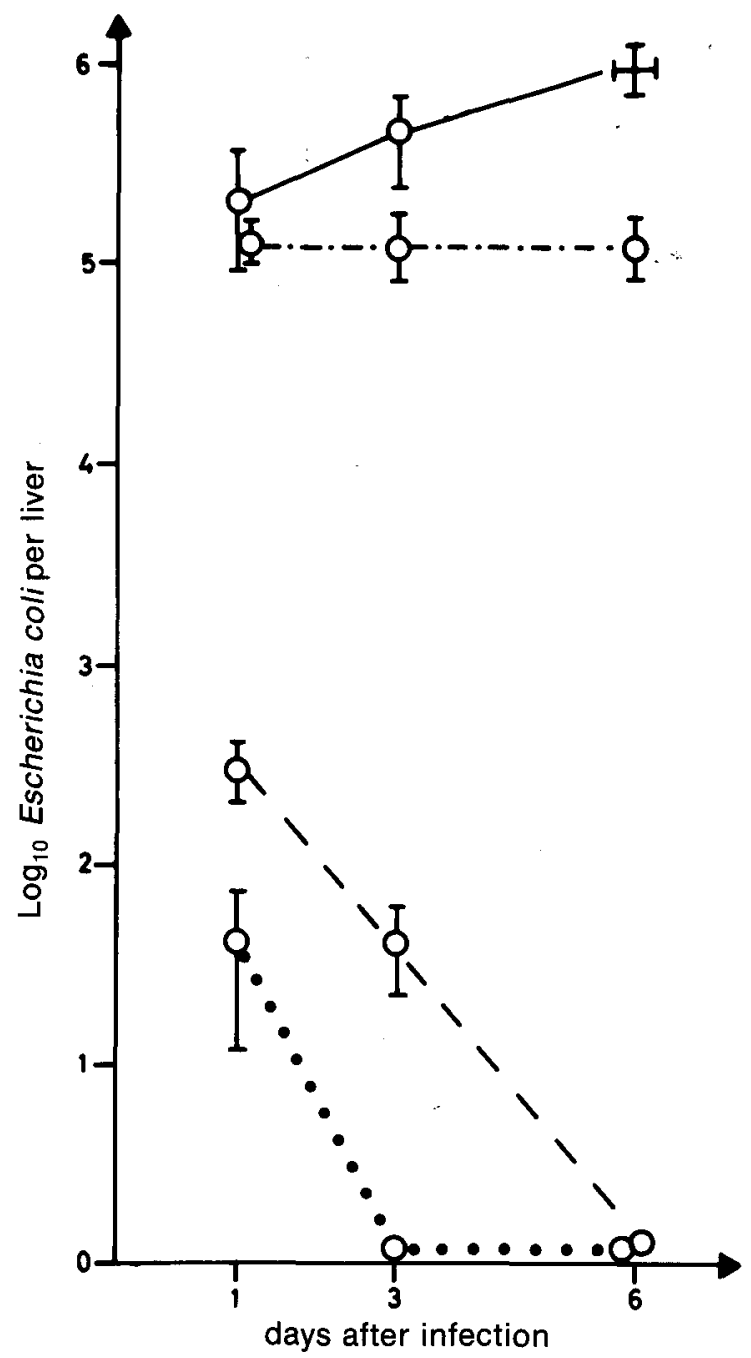

Figure 3: NMRI mice were infected subcutaneously with $10^{4}$ cells of Escherichia coli ATCC 25922 (-O) incorporated in agar. Some mice were treated orally with $2 \times 2 \mathrm{mg}$ amoxicillin (-. . . - 0-...-) or subcutaneously with $2 \times 2 \mathrm{mg}$ cotrimoxazole (-- $0---)$ or ceftriaxone (.........). The mean $\pm S E$ of bacterial counts per liver of five animals per group and day was determined. 
H. Hof et al.: Chemotherapy of E. coli Infection

\section{Literature}

1. Joiner, K. A., Onderdonk, A. B., Gelfand, J. A., Bartlett, J. G., Gorbach, S. L.: A quantitative model for subcutaneous abscess formation in mice. Br. J. Exp. Pathol. 61 (1980) 97-107.

2. Reznikov, M., Hakendorf, P. H., Matthews, D. B.: Response of a "susceptible" Escherichia coli to metronidazole therapy: an investigation using experimental subcutaneous abscesses. Chemotherapy 31 (1985) 50-54.

3. Walker, C. B., Wilkins, T. D.: Use of semisolid agar for initiation of pure Bacteroides fragilis infection in mice. Infect. Immun. 14 (1976) 721-725.

4. Bauernfeind, A., Petermüller, C.: In vitro activity of ciprofloxacin, norfloxacin and nalidixic acid. Eur. J. Clin. Microbiol. 2 (1983) 111-115.

5. Giamarellou, H., Efstratiou, A., Tsagarakis, J., Petrikkos, G., Daikos, G. K.: Experience with ciprofloxacin in vitro and in vivo. Arzneimittelforsch./Drug Res. 34 (1984) 1175-1178.
6. Clowes, R. C., Hayes, W.: Experiments in microbial genetics. Blackwell Scientific Publications, Oxford/Edinburgh 1968.

7. Spitalny, G. L.: Dissociation of bacterial activity from other functions of activated macrophages in exudates induced by thioglycollate medium. Infect. Immun. 34 (1981) 274-284.

8. Verweij-van Vught, A. M. J. J., Namavar, F., Sparrius, M., Vel, W. A. C., MacLaren, D. M.: Pathogenic synergy between Escherichia coli and Bacteroides fragilis: studies in an experimental mouse model. J. Med. Microbiol. 19 (1985) 325-331.

9. Hacker, J., Hof, H., Emödy, L., Goebel, W.: Influence of cloned Escherichia coli hemolysin genes and other virulence factors on pathogenicity in different animal models. Microb. Pathogen. (1986) (in print).

10. Engle, E. C., Manes, S. H., Drlica, K.: Differential effects of antibiotics inhibiting gyrase. J. Bacteriol. 149 (1982) 92-98.

11. Smith, J. T.: Mutational resistance to 4-quinolone antibacterial agents. Eur. J. Clin. Microbiol. 3 (1984) 347-350. 